Winners and Losers 
A volume in the series

\section{Cornell Studies in Political Economy \\ Edited by Peter J. Katzenstein}

A full list of titles in the series appears at the end of the book. 


\title{
Winners and Losers
}

\author{
How Sectors Shape \\ the Developmental Prospects \\ of States
}

\section{Michael Shafer}

Cornell University Press

Ithaca and London 


\section{Copyright $@ 1994$ by Cornell University}

All rights reserved. Except for brief quotations in a review, this book, or parts thereof, must not be reproduced in any form without permission in writing from the publisher. For information, address Cornell University Press, Sage House, 512 East State Street, Ithaca, New York 1485 o.

First published 1994 by Cornell University Press.

Printed in the United States of America

(0) The paper in this book meets the minimum requirements of the American National Standard for Information Sciences-Permanence of Paper for Printed Library Materials, ANSI Z39.48-1984.

\section{Library of Congress Cataloging-in-Publication Data}

Shafer, D. Michael, 1953-

Winners and losers : how sectors shape the developmental prospects of states / D. Michael Shafer.

p. $\quad \mathrm{cm}$. - (Cornell studies in political economy)

Includes bibliographical references and index.

ISBN o-8014-3000-3 (alk. paper). — ISBN o-8o14-8188-o (pbk.)

1. Developing countries-Economic policy-Case studies. 2. Developing countries-Industries-Case studies. I. Title. II. Series.

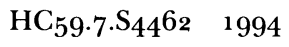

$338.9^{\prime} 1^{\prime} 091724$-dc2o

$94^{-10383}$ 
Dedicated to my children

Moon Hee, Byung Bum, Jeong Deok, and Jeong Hwan 
